\title{
THE EFFECT OF REYNOLDS NUMBER OF AIR FLOW DURING THE AIR STERILIZATION PROCESS WITH ULTRAVIOLET GERMICIDAL IRRADIATION LAMP
}

\author{
Giorgos Kouropoulos \\ Department of Energy Technology, Technological Educational Institution, Athens, Greece, \\ e-mail: etmecheng@gmail.com
}

Received Date: August 23, 2019; Revised Date: October 4, 2020; Acceptance Date: February 11, 2021

\begin{abstract}
This case study examines the effect that the Reynolds number of air flow has on the population of live pathogenic microorganisms during the process of air sterilization using ultraviolet germicidal irradiation (UVGI) lamp in a closed air-duct. With this aim, the first discussion is the mathematical model which regulates changes to the Reynolds number in terms of the percentage of population for the following live pathogenic microorganisms: Escherichia coli, Mycobacterium tuberculosis and Streptococcus pneumoniae, under special condition of flow rate and intensity of UV irradiation. In conclusion, as the velocity and the Reynolds number of the air flow in the duct increases, the exposure time of the pathogens to the field of UV-C irradiation decreases, the effect of UV-C irradiation and the germicide capabilities of the UVGI lamp are reduced. Consequently, the population of live pathogenic microorganisms increases.
\end{abstract}

Keywords: Air sterilization, Germicidal irradiation, Reynolds number, Ultraviolet lamp, UVGI lamp

\section{Introduction}

UVGI lamps consist of technology which is applied for the sterilization and disinfection of air from pathogenic microorganisms. The UVGI lamp emits ultraviolet UV-C radiation. This radiation is categorised officially at the broad wavelength of $100-280 \mathrm{~nm}$ of the electromagnetic phase [1]. It is, however, active against microorganisms at a wavelength of $180-320 \mathrm{~nm}$, while it presents the greatest effect at approximately $265 \mathrm{~nm}$ [2]. The UV-C radiation that UVGI lamps emit does not remove the pathogens but rather slows down their development, inhibits their proliferation and deactivates them. It is, therefore, apparent that the mechanism of the UVGI lamps is not similar to other system, such as filters which are designed to remove and eliminate microorganisms. This sterilization technology has a wide field of application in the field of medicine. In fact, sixty percent of UVGI sterilization systems are used in hospitals [3]. UVGI lamps are placed in the air-duct where the conditioned air from the heating, ventilation and air-conditioning (HVAC) system travels. Usually, before the placement of the lamps, high-efficiency particulate air (HEPA) filters are installed. In this way, any airborne pathogens that manage to penetrate the air filter will pass into the UV-C irradiation field of action leading to their deactivation. The simultaneous use of the two systems produces a higher rate of efficacy to the air sterilization system. There are two fundamental categories of systems that use UVGI lamps: air disinfection systems and surface disinfection systems. Air sterilization with UVGI lamps in air-ducts are classed in the former category [4]. 


\section{Mathematical Model of the Air Sterilization Process with UVGI Lamp}

In the simplest case of a deactivation process of pathogens by ultraviolet irradiation, pathogenic microorganisms are on a surface within a closed chamber in which there is a UVGI lamp. In such case, no flow of air occurs as would occur in an air-duct system via an air pump.

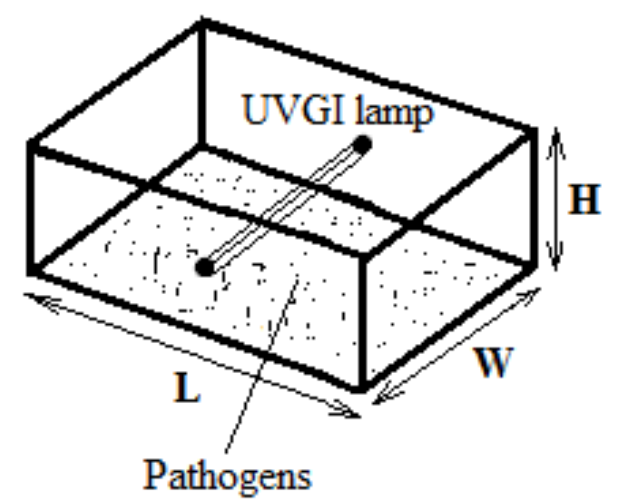

Figure 1. Surface sterilization process of pathogens in an enclosed chamber

When the pathogenic microorganisms are under the effect of UV-C germicidal irradiation, the correlation between the percentage $S$ of live pathogens and the time $t$ in which the microorganisms are exposed to the irradiation, is given by the following formula [5]

$$
S(t)=\exp (-k I t)
$$

Where: S: Percentage of survival pathogens and microorganisms (\%).

$\mathrm{k}$ : Rate constant that is dependent by pathogen $\left(\mathrm{cm}^{2} / \mu \mathrm{J}\right)$.

I: Intensity of UV irradiance $\left(\mu \mathrm{W} / \mathrm{cm}^{2}\right)$.

t: Exposure time on the UVGI lamp (sec).

The percentage of live pathogenic microorganisms $\mathrm{S}$ for any given moment in time $S_{t}$ can be estimated also by the following formula:

$$
S=\frac{S_{0}-S_{t}}{S_{0}}
$$

Where: $S_{0}$ : Initial population of live pathogens at time $\mathrm{t}=0$.

$S_{t}$ : Population of live pathogens at time $\mathrm{t}>0$.

In certain pathogens, the deactivation procedure with UV-C radiation consists of two stages in which each one presents a different response speed [5]: in such a case, the following equation is applied:

$$
S(t)=\left(1-f_{R}\right) \exp \left(-k_{f} I t\right)+f_{R} \exp \left(-k_{s} I t\right)
$$

Where: $\mathrm{k}_{\mathrm{f}}$ : Rate constant for the fast stage of inactivation process $\left(\mathrm{cm}^{2} / \mu \mathrm{J}\right)$.

$\mathrm{k}_{\mathrm{s}}$ : Rate constant for the slow stage of inactivation process $\left(\mathrm{cm}^{2} / \mu \mathrm{J}\right)$.

$f_{R}$ : Resistance fraction of each pathogen. 
The constants $k k_{f} k_{s}$ as well as the fraction of resistance $f_{R}$ are estimated experimentally for each pathogenic microorganism and are selected from bibliographies, such as [5-12]. The intensity of the irradiation that the UVGI lamp emits depends on the transmitted power output and the geometrical characteristics of the lamp. For a circular cross-section lamp, the intensity is estimated by the following formula:

$$
I=\frac{P_{o}}{A}=\frac{P_{o}}{2 \pi r l}
$$

$P_{o}$ the output power of UVGI lamp $(\mu \mathrm{W}) ; \mathrm{r}$ the radius of UVGI lamp $(\mathrm{cm}) ; 1$ the length of UVGI lamp $(\mathrm{cm})$. The greater the distance from the lamp's surface, the less the intensity of the irradiation. When the sterilization process of air in a closed chamber occurs as in Figure 1, the intensity of the UV-C irradiation of the lamp is calculated for a radius equal to the distance of the lamp from the top and the bottom of the chamber, so in the case of a lamp placed in the center, in Equation (4), $r=H / 2$.

The capability of a UVGI lamp to deactivate pathogens depends directly on the intensity of the radiation emitted and the type of microorganism, while indirectly it depends on various factors such as temperature [13] and the relative humidity [4] [14-15].

\section{In-Duct Sterilization Process with UVGI Lamp}

In the sterilization process of air with a UVGI lamp within a duct, the UVGI lamp is located in the air-duct in which a flow of air is present. The flow is sped up with the use of a pump and the airborne pathogens travel within the irradiation field of operation of the lamp, thus leading to their deactivation (Figure 2). For the sterilization process within a duct, the Equations (1) - (4) apply:
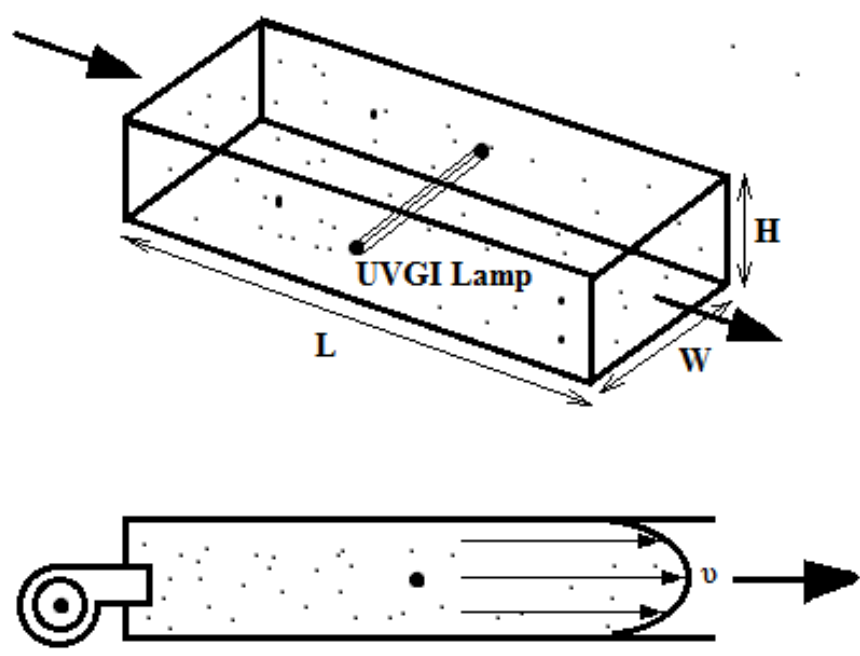

Figure 2. In-duct air sterilization process

With regards to the sterilization of air within an air-duct, the exposure time of the pathogens to UV irradiation differentiates in comparison to a static condition in which no air flow is present as in the case of Figure 1. The exposure time of airborne pathogens may be determined by the average velocity at which the pathogens travel in fluid and the length of the air-duct. 


$$
t=\frac{L}{u_{p}}
$$

Where: $u_{P}$ : Average velocity of airborne pathogens $(\mathrm{cm} / \mathrm{sec})$.

L: Duct length of UVGI system (cm).

t: Exposure time of airborne pathogens to the UVGI lamp (sec).

If in Equation (5) we multiply both $\mathrm{L}$ and $u_{P}$ with the cross-sectional area of the air-duct, then the ratio becomes the volume $\mathrm{V}$ of the air-duct over the average air supply $\mathrm{Q}$ of the air-duct.

\section{Relationship Between Reynolds Number and Percentage of Survival Pathogens}

The air flow in an air-duct is distinguished between laminar and turbulent flow. With regards to the laminar flow, it is considered that lines of fluid flow move in parallel to the duct axis. As for the turbulent flow, the lines of fluid flow have an irregular direction along the duct axis. The type of flow is determined by the Reynolds number. Laminar flow predominates when $\mathrm{Re}<2300$, while turbulent flow predominates when $\mathrm{Re}>2900$, and in the range of $2300<\operatorname{Re}<2900$, a transition state predominates.

Laminar air flow is not easily attained by a HVAC system. For a $\mathrm{Re} \leq 2300$ to dominate in a circular cross-section duct with a $0.5 \mathrm{~m}$ diameter, an air velocity $u_{f} \leq 0.22$ $\mathrm{m} / \mathrm{sec}$ at $23^{\circ} \mathrm{C}$ must be maintained. The minimum requirement for ventilation of a space is $0.3 \mathrm{Ls}^{-1} \mathrm{~m}^{-2}$ and $2.5 \mathrm{Ls}^{-1}$ per person [16] therefore, for a small structure of at least 200 $\mathrm{m}^{2}$ with an HVAC system and central ventilation ducts with UVGI lamps, an air velocity flow $0.34 \mathrm{~m} / \mathrm{sec}$ emerges. Consequently, in the majority of HVAC installations turbulent air flow occurs. The Reynolds number of fluid for a rectangular air-duct cross-section, are calculated from the following equation:

$$
R e=\frac{2 u_{f}}{v} \frac{w h}{(w+h)}
$$

The fluid velocity in the duct can be expressed as a function of Reynolds number:

$$
u_{f}=\mathrm{vRe} \frac{(w+h)}{2 w h}
$$

$u_{f}$ the velocity of air $(\mathrm{m} / \mathrm{sec})$; $v$ the kinematic viscosity of air $\left(\mathrm{m}^{2} / \mathrm{sec}\right)$; w the width of the duct $(\mathrm{m})$; and $\mathrm{h}$ the height of the duct $(\mathrm{m})$. The velocity of the airborne pathogens $u_{P}$ in reality are not always equal to the velocity of a fluid flow $u_{f}$, even though they may be determined if the velocity of the fluid flow and other facts on the basis of experiential relationships is known [17-18], resolving in relation to $u_{P}$.

$$
\frac{u_{p}}{u_{f}}=\left[1+C\left(\frac{\rho_{p}}{\rho_{f}}-1\right)^{\frac{2}{3}}\left(\frac{d_{p}}{d_{h}}\right)\left(1+\frac{200}{F r-F r_{0}}\right)\right]^{-1}
$$


Where: $\lambda$ : $\quad$ Velocity ratio $u_{P} / u_{f}$ in equation 7.

$\rho_{f}$ : Density of air $\left(\mathrm{Kg} / \mathrm{m}^{3}\right.$ or $\left.\mathrm{gr} / \mathrm{cm}^{3}\right)$.

$\rho_{P}:$ Buoyant density of pathogen microorganism $\left(\mathrm{Kg} / \mathrm{m}^{3}\right.$ or $\left.\mathrm{gr} / \mathrm{cm}^{3}\right)$.

C: Dimensionless parameter that varies between $0.014-0.05$.

$\mathrm{d}_{\mathrm{h}}$ : Hydraulic diameter of duct for a rectangular section.

$\mathrm{d}_{\mathrm{P}}$ : Average diameter of pathogen $(\mu \mathrm{m})$.

Fr: Froude number of air.

$\mathrm{Fr}_{0}$ : Froude number calculated for the settling velocity of pathogen.

The hydraulic diameter for a rectangular duct is equal to the following:

$$
d_{h}=\frac{2 w h}{w+h}
$$

The Froude number of air is equal to the following:

$$
F r=\frac{u_{f}}{\sqrt{g L}}
$$

The settling velocity of the airborne pathogen is equal to the following:

$$
u_{S}=\frac{\left(\rho_{p}-\rho_{f}\right) g d_{p}^{2}}{18 \mu}
$$

Stokes law predicts the settling velocity $u_{S}$ for a pathogen. The Froude number $\mathrm{Fr}_{0}$ is equal to the following:

$$
F r_{0}=\frac{u_{S}}{\sqrt{g L}}=\frac{\left(\rho_{p}-\rho_{f}\right) d_{p}^{2}}{18 \mu} \sqrt{\frac{g}{L}}
$$

Where: $\mu$ : Dynamic viscosity of air $\left(\mathrm{N} \times \mathrm{sec} / \mathrm{m}^{2}\right)$.

g: Gravitational acceleration $\left(9.81 \mathrm{~m} / \mathrm{sec}^{2}\right)$.

$u_{S}$ : Settling velocity of the airborne pathogen $(\mathrm{m} / \mathrm{sec})$.

In Equation (11), if $\rho_{\mathrm{P}}<\rho_{\mathrm{f}}$ then $\mathrm{Fr}_{0}<0$, therefore, the result of relationship (7) is $\mathrm{Fr}_{0}=0$. By replacing (6b) with (7), by substituting (8), (9), (11) with (7), with resolution of (7), as regards the velocity of the airborne pathogens $u_{P}$ and substitution of $u_{P}(R e)$ with (5), the correlation of the time the pathogens are exposed to UV irradiation of the Reynolds number emerges. From Equation (1) and (3), depending on the case, the final function $\mathrm{S}(\mathrm{Re})$ emerges. The exposure time of the pathogens in relation to the Reynolds number $\mathrm{t}(\mathrm{Re})$, is given in relationship (12):

$$
t=\frac{1}{R e} \frac{L d_{h}}{\lambda v}
$$




\section{Application of the Mathematical Model}

The mathematical model, Equations (1)-(12) is applied to three different pathogenic microorganisms: Escherichia coli with average buoyant density $1.09 \mathrm{gr} / \mathrm{cm}^{3}$ and rate constant $0.003759 \mathrm{~cm}^{2} / \mu \mathrm{J}$, Mycobacterium tuberculosis with average buoyant density $1.075 \mathrm{gr} / \mathrm{cm}^{3}$ and average rate constant $0.00261 \mathrm{~cm}^{2} / \mu J$, and Streptococcus pneumoniae with average buoyant density $1.465 \mathrm{gr} / \mathrm{cm}^{3}$ and rate constant $0.0000492 \mathrm{~cm}^{2} / \mu J$.

The choice of values for the buoyant density $\rho_{P}$ and rate constant $\mathrm{k}$ is presented in Table 1 and Table 2. Buoyant density is the density of a microorganism's DNA. To calculate this density, the procedure is as follows in brief: The microorganism is immersed in a chemical solution of cesium chloride, after which with the use of special equipment the centrifugation procedure or density-gradient centrifugation the particles that contain the DNA are separated from the other structural elements of the microorganism, and the final calculation is based on the principle of buoyance and Archimedes' principle. For each pathogen, the change in the survival percentage at $36 \mathrm{~W}, 72 \mathrm{~W}$ and $100 \mathrm{~W}$ UV intensity is examined. Thus three different response curves for each microorganism are extracted in Figure 3, Figure 4, and Figure 5.

Table 1. Average Selected Values of Buoyant Density $\rho_{P}$

\begin{tabular}{|c|c|c|c|}
\hline Pathogens & $\begin{array}{c}\text { Buoyant } \\
\text { Density gr/cm }\end{array}$ & Reference & $\begin{array}{c}\text { Average } \\
\text { Value }\end{array}$ \\
\hline Escherichia Coli & $1.08-1.1$ & [19] & 1.09 \\
\hline Mycobacterium Tuberculosis & $1.02-1.13$ & [20] & 1.075 \\
\hline Streptococcus Pneumoniae & 1.45 or 1.48 & [21] & 1.465 \\
\hline
\end{tabular}

Table 2. Average Selected Values of Rate Constant $k$

\begin{tabular}{|c|c|c|c|}
\hline Pathogens & $\begin{array}{c}\text { Rate Constant } \\
\mathrm{cm}^{2} / \mu \mathrm{J}\end{array}$ & Reference & $\begin{array}{c}\text { Average } \\
\text { Value }\end{array}$ \\
\hline Escherichia Coli & 0.003759 & {$[7]$} & 0.003759 \\
\hline Mycobacterium Tuberculosis & $\begin{array}{l}0.000987 \\
0.002132 \\
0.004721\end{array}$ & $\begin{array}{l}{[11]} \\
{[22]} \\
{[15]}\end{array}$ & 0.00261 \\
\hline Streptococcus Pneumoniae & 0.0000492 & [4] & 0.0000492 \\
\hline
\end{tabular}

Below follows the numeric values of all of the parameters and sizes for the application of the mathematical model, the extraction of the response curves and drawing conclusions. Numerical correlations from (13) to (21) on Figures 3, 4 and 5, have the following form in Equation 13, the variable $\mathrm{A}$ is a real number.

$$
S(R e)=\exp \left(-\frac{A}{R e}\right)
$$


Table 3. Numerical Values and Other Parameters for Escherichia Coli

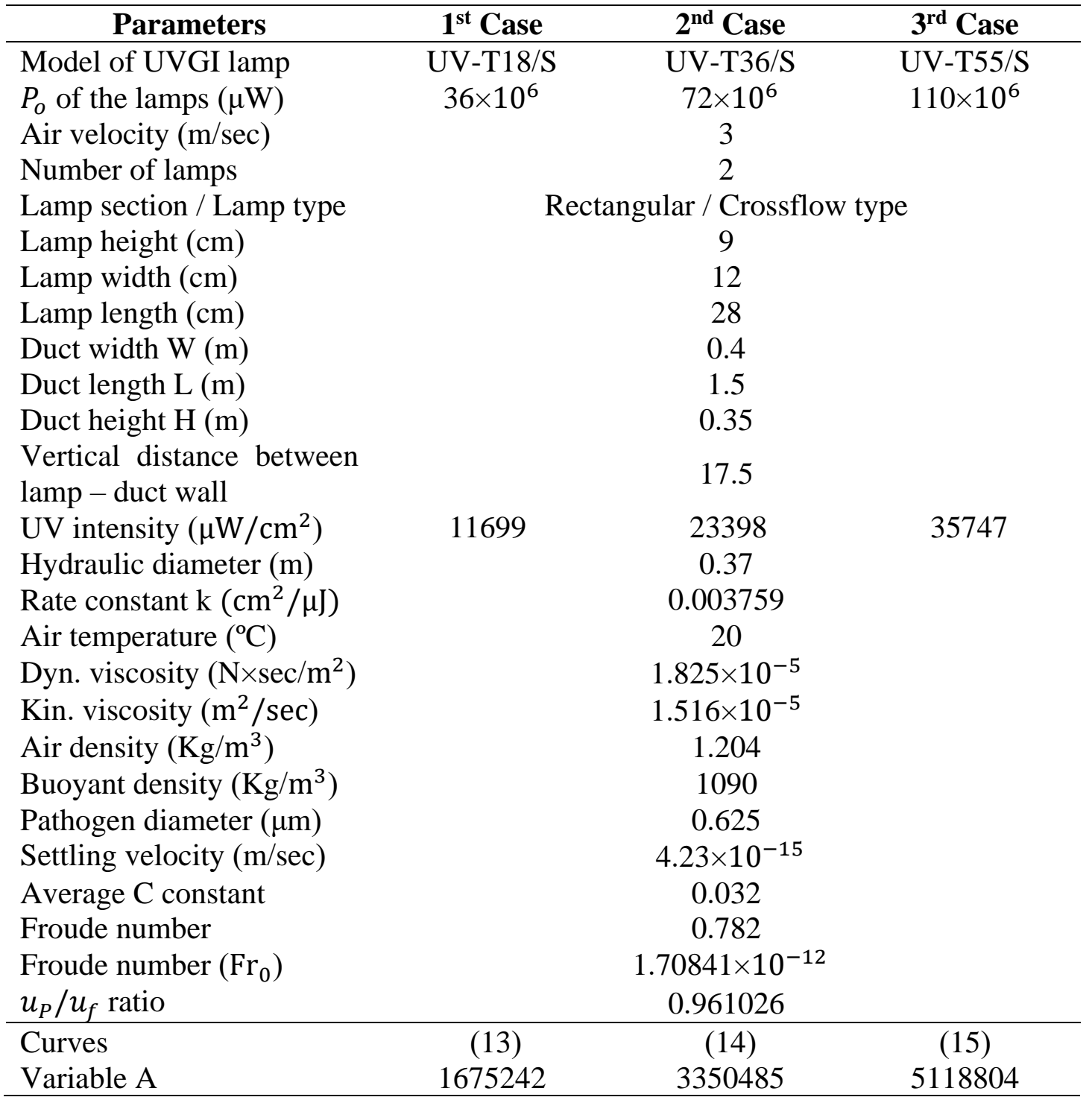

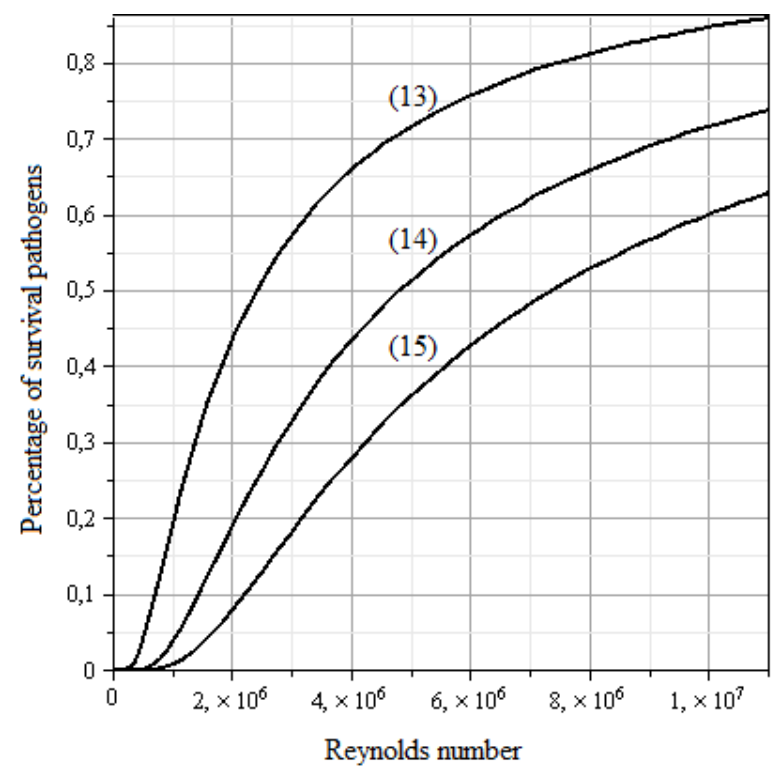

Figure 3. Numerical relationship between survival percentage of Escherichia coli and Reynolds number of air for three different UV intensity values 
Table 4. Numerical Values and Other Parameters for Mycobacterium Tuberculosis

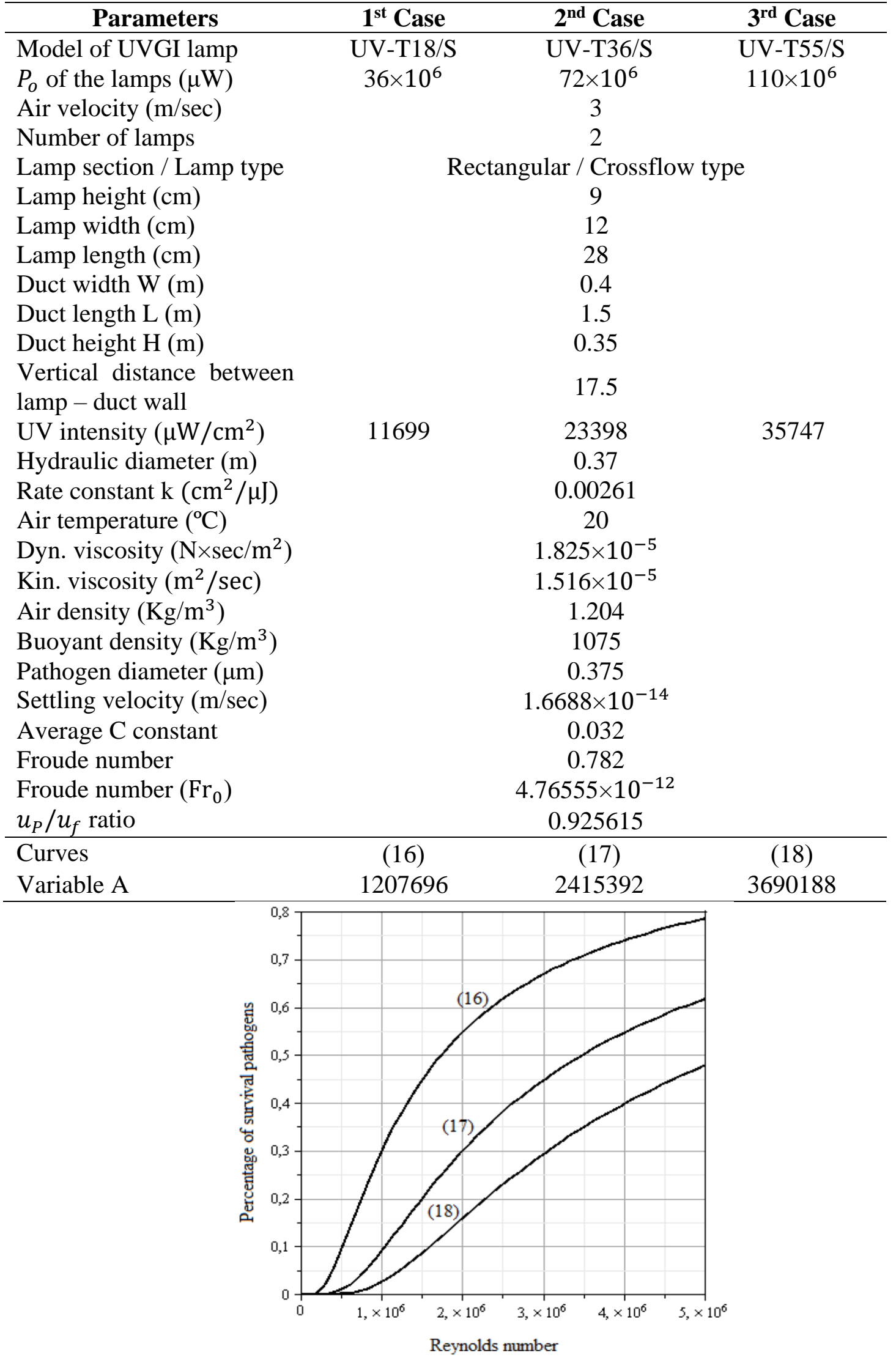

Figure 4. Numerical relationship between survival percentage of Mycobacterium tuberculosis and Reynolds number of air for three different UV intensity values 
Table 5. Numerical Values and Other Parameters for Streptococcus Pneumoniae

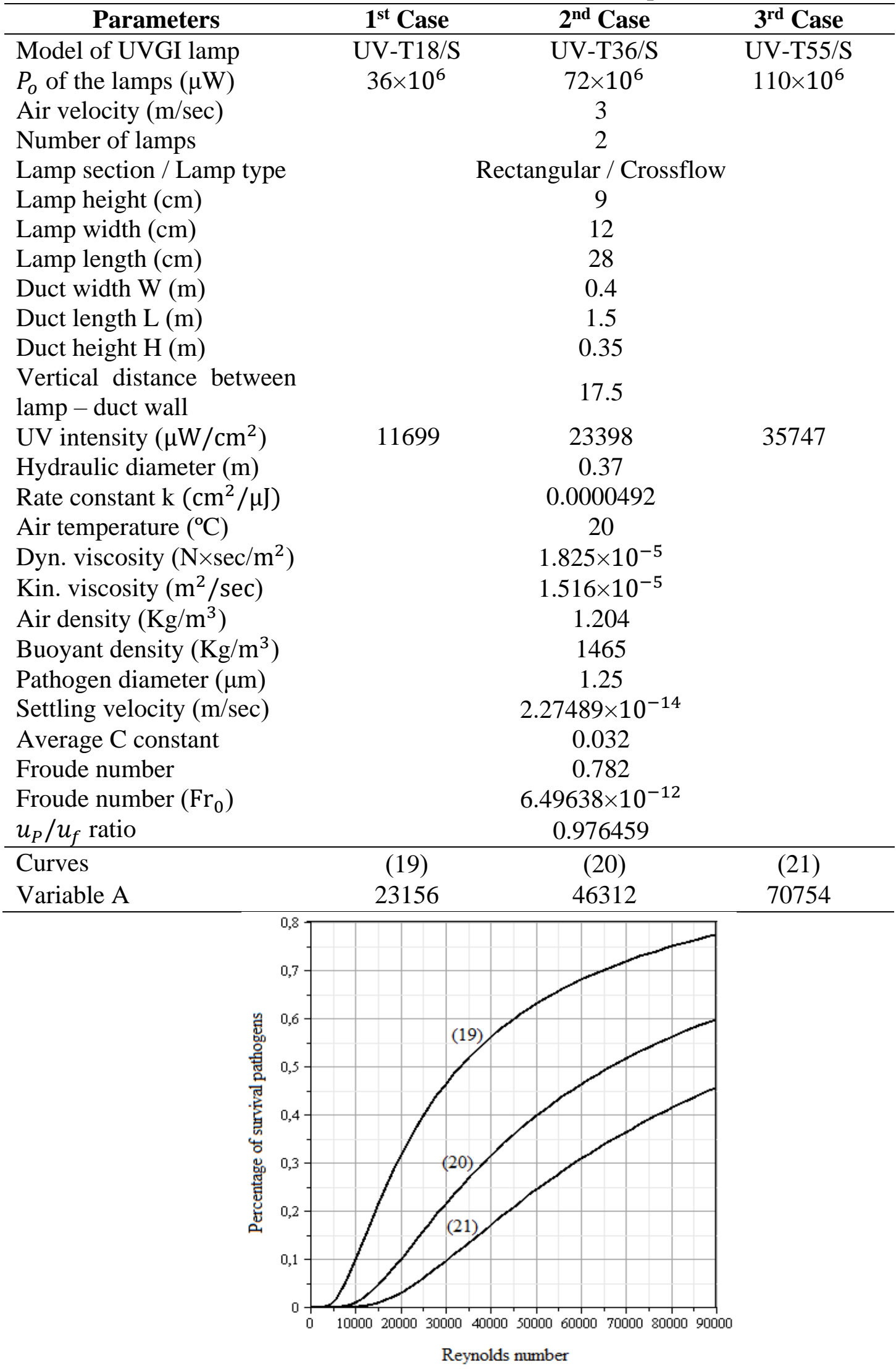

Figure 5. Numerical relationship between survival percentage of Streptococcus pneumoniae and Reynolds number of air for three different UV intensity values 


\section{Discussion}

In this study it was endeavored to determine how the population of live pathogenic microorganisms is changed in relation to Reynolds number of air flow during the air sterilization with UV-C irradiation within a closed duct using a UVGI lamp. The mathematical model was discussed and developed, which connects numerically the change in the percentage of pathogen deactivation in accordance with the Reynolds number, and calculations were conducted for pathogens: Escherichia coli, Mycobacterium tuberculosis and Streptococcus Pneumoniae. The motion and trajectory of microorganisms execute as they move through the air-duct is unpredictable and irregular. At any given time, the pathogens are found in a different position; as a consequence, the distance between pathogens and the UVGI lamp is never constant and by extension there is no steady value for the intensity of irradiation of the lamp. It is preferable, therefore, to conduct the extraction of the function curve $\mathrm{S}(\mathrm{Re})$ for three different values of intensity of UV-C irradiation. From the curves in Figure 3, Figure 4 and Figure 5, it is clear that each microorganism presents a different response during its exposure to UV-C irradiation. The application of the mathematic model for the pathogenic microorganisms mainly concerns laboratory conditions. This is due to the fact that during an experimental application, the conditions are monitored, controlled and constant, while in an actual application, the conditions may be dynamic, as for instance the air velocity, temperature and relative humidity of air.

\section{Conclusions}

According to the mathematical model, the percentage of deactivation of pathogenic microorganisms by ultraviolet UV-C irradiation during sterilization of the air in a closed air-duct changes exponentially in relation to the Reynolds number of air flow. As the air flow velocity increases, the Reynolds number of air flow increases and the exposure time of the pathogens to the field of UV-C irradiation decreases. The lower the exposure time of the pathogens to the irradiation of UVGI lamp the lower the deactivation percentage. The higher the intensity of the UVGI lamp radiation, the higher the percentage of pathogen deactivation for the same flow conditions. The reduction in the percentage of pathogen deactivation due to the increase in Reynolds number may be offset by the increase in intensity of the ultraviolet rays of the UVGI lamp. Each microorganism exhibits a different response to ultraviolet irradiation, which is due to the different constant $\mathrm{k}$ of each pathogenic microorganism.

\section{References}

[1] International Organization for Standardization, "ISO 21348: Space Environment Natural and Artificial - Process for Determining Solar Irradiances," 2007 [online]. Available: https://www.iso.org/standard/39911.html [Accessed: August 2019]

[2] C.C.E. Meulemans, "The basic principles of UV-disinfection of water," Ozone: Science \& Engineering, Vol. 9, No. 4, pp. 299-313, 1987. doi:10.1080/01919518708552146

[3] F. Memarzadeh, R.L. Olmsted, and J.M. Bartley, "Applications of ultraviolet germicidal irradiation disinfection in health care facilities: Effective adjunct, but not stand-alone technology," American Journal of Infection Control, Vol. 38, No. 5, pp. S13-S14, 2010. doi:10.1016/j.ajic.2010.04.208 
[4] W. Kowalski, Ultraviolet Germicidal Irradiation Handbook, UVGI for air and surface disinfection, Springer-Verlag Berlin Heidelberg, 2009. doi:10.1007/978-3642-01999-9_7

[5] W.J. Kowalski, W.P. Bahnfleth, D.L. Witham, B.F. Severin, and T.S. Wittam, "Mathematical modeling of ultraviolet germicidal irradiation for air disinfection," Quantitative Microbiology, Vol. 2, No. 3, pp. 249-270, 2000. doi:10.1023/A:1013951313398

[6] G. Sharp, "The lethal action of short ultraviolet rays on several common pathogenic bacteria," Journal of Bacteriology, Vol. 37, No. 4, pp. 447-459, 1939.

[7] G. Sharp, "The effects of ultraviolet light on bacteria suspended in air," Journal of Bacteriology, Vol. 38, pp. 535-547, 1940.

[8] N. Luckiesh and Matthew, Applications of Germicidal, Erythemal and Infrared Energy, Van Nostrand, New York, 1946.

[9] M.M. Jensen, "Inactivation of airborne viruses by ultraviolet irradiation," Applied and Environmental Microbiology, Vol. 12, No. 5, pp. 418-420, 1964.

[10] W.F. Hill, F.E. Hamblet, W.H. Benton, and E.W. Akin, "Ultraviolet devitalization of eight selected enteric viruses in estuarine water," Applied and Environmental Microbiology, Vol. 19, No. 5, pp. 805-812, 1970.

[11] H.L. David, "Response of mycobacteria to ultraviolet light radiation," The American Review of Respiratory Disease, Vol. 108, No. 5, pp. 1175-1184, 1973. doi:10.1164/arrd.1973.108.5.1175

[12] A. Asthana and R.W. Tuveson, "Effects of UV and phototoxins on selected fungal pathogens of citrus," International Journal of Plant Science, Vol. 153, No. 3, pp. 442-452, 1992. doi:10.1086/297050

[13] B.F. Severin, M.T. Suidan, and R.S. Engelbrecht, "Effects of temperature on ultraviolet light disinfection," Environmental Science \& Technology, Vol. 17, No. 12, pp. 717-721, 1983. doi:10.1021/es00118a006

[14] J.L. Peccia and M.T. Hernandez, "UV-induced inactivation rates for airborne mycobacterium bovis BCG," Journal of Occupational and Environmental Hygiene, Vol. 1, No. 7, pp. 430-435, 2004. doi:10.1080/15459620490458495

[15] R.L. Riley and E.J. Kaufman, "Effect of relative humidity on the inactivation of airborne serratia marcescens by ultraviolet radiation," Applied Microbiology, Vol. 23, No. 6, pp. 1113-1120, 1972.

[16] ANSI/ASHRAE Standard 62.1-2013, Ventilation for Acceptable Indoor Air Quality [online]. Available: https://www.ashrae.org/file\%20library/technical\%20resources/standards\%20and\%2 0guidelines/standards\%20addenda/62_1_2013_p_20150707.pdf [Accessed: December 2020].

[17] J.A. Schetz and A.E. Fuhs, Fundamentals of Fluid Mechanics, Wiley-Interscience, New York, 1999.

[18] P. Schuchart, "Widerstandsgesetze beim pneumatischen transport in rohrkrummern," Chemie Ingenieur Technik, Vol. 40, No. 21-22, pp. 1060-1067, 1968. doi:10.1002/cite.330402107

[19] C.L. Woldringh, J.S. Binnerts, and A. Mans, "Variation in escherichia coli buoyant density measured in percoll gradients," Journal of Bacteriology, Vol. 148, No. 1, pp. 58-63. 1981. 
[20] A.L. der Hertog, P.R. Klatser, and R.M. Anthony, "Buoyant density of Mycobacterium tuberculosis: implications for sputum processing," International Journal of Tuberculosis and Lung Disease, Vol. 13, No. 4, pp. 466-471, 2009.

[21] H. Fraenkel-Conrat, The Viruses Catalogue, Characterization, and Classification, Springer US, New York, 1985. doi:10.1007/978-1-4613-2379-2

[22] F.M. Collins, "Relative susceptibility of acid-fast and non-acid-fast bacteria to ultraviolet light," Journal of Applied Microbiology, Vol. 21, No. 3, pp. 411-413, 1971. 